\title{
EUROPEAN UNION WATER POLICY IN ASPECT OF RURAL AREAS DEVELOPMENT
}

\author{
VODNÁ POLITIKA EURÓPSKEJ ÚNIE \\ Z POHL'ADU ROZVOJA VIDIECKYCH OBLASTÍ
}

\author{
Edward PIERZGALSKI*
}

\section{Introduction}

Water resources are extremely important factor in determining the meaning and development of rural areas. Problems associated with water can be divided into three categories: the water may be too little, too much, or may be polluted ${ }^{(1)(2)}$. Quantity and quality of water resources influence the health of the population through access to clean water, security of the population in flood risk zones, economic development (the level of plant and animal production), state of ecosystems and the development of non-productive functions of rural areas. Water issues are not isolated and separated problems in the rural development plans, contrary they are in close relation with all the economic, natural and social functions of the rural areas. The most important tasks of water management in the rural areas are:

- water supply for domestic use and for agricultural production (proper quantity and quality),

- mitigation of extreme hydrological phenomena effects such as floods and droughts,

- protection of water resources against pollution (sewage, animal wastes),

- conservation of natural habitats.

The water resources in the EU countries vary and they are unevenly distributed in space and time ${ }^{(3)}$. The most important issue seems to be the high water pollution ${ }^{(4)(5)}$. This applies to more than $50 \%$ of surface water. Serious water shortages are particularly in the countries of southern Europe. Overall, it is estimated that $60 \%$ of cities over-exploit the groundwa-

(1) EEA, 2012: Report: European waters - assessment of status and pressures. No 8/2012.

(2) Kundzewicz Z., Zalewski M., Kędziora A., Pierzgalski E., 2010: Zagrożenia związane z wodą. Nauka, 4/2010, 87 - 96.

(3) EEA, 2012a: Towards efficient use of water resources in Europe, EEA Report No 1/2012, European Environment Agency (http://www.eea.europa.eu/publications/towards-efficient-use-of-water).

(4) EEA, 2012d: European waters - current status and future challenges (Synthesis). EEA Report No 9/2012. European Environment Agency, Copenhagen (http://www.eea.europa. eu/publications\#c $9=a 11 \& c 14=\& c 12=\& c 7=e n \& c 11=5 \& b$ start $=0$ \&c $5=$ water)

(5) EEA, 2012, European bathing water quality in 2011, EEA Report No 3/2012, European Environment Agency (http://www. eea.europa.eu/publications/european-bathing-waterquality-in-2011)

\section{Abstract (EN)}

Agriculture and environment are among others the most important priorities of the European Union. Agriculture is strongly influenced by the state of the environment, including water resources. In addition to many other policies, the EU water policy is crucial for the sustainable development of rural areas. Directives are the main tools for implementation of water policy. This article contains an overview of the directives on aspects of quality and quantity of water resources. Within the paper three most important agricultural areas of the Directive are characterized: the Water Framework Directive, the Floods Directive and the Nitrates Directive. Presented mandatory EU action aimed at their implementation and the problems associated with it. Current proposals for changes in the EU water policy are described.

\section{Keywords (EN)}

water resources, water policy, rural areas, European Union

\section{Abstrakt (SK)}

Polnohospodárstvo a životné prostredie sú jedným z najdôležitejších priorít Európskej únie. Polnohospodárstvo je silne ovplyvnené stavom životného prostredia vrátane vodných zdrojov. Okrem mnohých iných politík, vodná politika EÚ je zásadná pre udržatel'ný rozvoj vidieckych oblastí. Smernice sú hlavným nástrojom, prostredníctvom ktorého je realizovaná vodná politika. Tento článok obsahuje prehlad smerníc o kvalitatívnych a kvantitatívnych aspektoch vodných zdrojov. Charakterizuje tri najdôležitejšie pol'nohospodárske oblasti tejto smernice: Rámcovú smernicu o vode, Smernicu o povodniach a Smernicu o dusičnanoch. Prezentované povinné opatrenia na úrovni EÚ sú zamerané na ich realizáciu a problémy s nimi spojené. V článku sú opísané tieź súčasné návrhy na zmeny vodnej politiky EU.

\section{Klúčové slová (SK)}

vodné zdroje, vodná politika, vidiecke oblasti, Európska únia

ter resources. What is more, severe losses and destruction are caused by droughts and floods.

Current determinants require a new approach for water factor in rural development. First of all, the water should not be considered apart from spatial plans, which cover agricultural production area, areas of settlement, technical infrastructure, as well as ecosystems, including water biotopes. All projects related to water management should take into account the experience gained from implemented investments.

The most significant contemporary challenges of water

* Warsaw University of Life Sciences - SGGW 
management in rural areas include the need to comply with the EU environmental requirements, the implementation of sustainable development of rural areas policies on local, national and regional levels as well as the need to adapt to climate change $\mathrm{e}^{(6)(7)(8)(9)(10)}$.

Directives are the main tools for shaping the water policy of the EU. Until now, more than 20 different EU directives relating to the water was enacted. The first directive on water resources was adopted in the 70s of the last century in the European Economic Community. They concerned the required quality of surface water intended for the abstraction of drinking water (1975), the quality of bathing water (1976), pollution caused by certain dangerous substances discharged into the aquatic environment (1976), the quality of fresh waters in the need for protection or improvement for fish life (1978), methods of measurement and frequencies of sampling and analysis of surface water intended for the abstraction of drinking water (1979), the water quality for shellifish (1976), the protection of groundwater against pollution caused by certain dangerous substances (1979). The last two EEC directives were adopted in 1991 and they were related to urban waste water treatment ${ }^{(11)}$ and to protection of waters against pollution by nitrates from agricultural sources. This last important directive is commonly known as the Nitrates Directive ${ }^{(12)}$.

In 2000 the European Parliament adopted a directive for establishing a framework for Community action in the field of water policy, the Water Framework Directive ${ }^{(13)}$. Later, several other directives have been adopted: in 2006 the directive on the management of bathing water quality replacing directive from 1976, in the same year a directive on pollution caused by certain dangerous substances discharged into the aquatic environment and the directive on the protection of groundwater against pollution and deterioration. In 2007

(6) EC, 2007, Communication from the Commission to the European Parliament and to Council addressing the challenge of water scarcity and droughts in the European Union (COM (2007) 414 final of 18 July 2007).

(7) EC, 2010, Final Report from the Commission to the Council and the European Parliament: Second Follow-up Report to the Communication on water scarcity and droughts in the European Union $(\mathrm{COM}(2007) 414$ final $(\mathrm{COM}(2010) 228$ of 18 May 2010).

(8) EEA, 2012, Climate change, impacts and vulnerability in Europe 2012 - An indicator-based report. EEA Report No.12/2012.

(9) Fallon P. and Betts R., 2010: Climate Impacts on European Agriculture and Water Management in the Context of Adaptation and Mitigation - The Importance of an Integrated Approach. Science of the Total Environment, 408(23), 5667 - 5687.

(10) EEA2012: Climate change and water adaptation issues, EEA Technical report No 2/2007, European Environment Agency (http://www.eea.europa.eu/publications/technical_ report_2007_2)

(11) Council Directive 91/271/EEC concerning urban waste - water treatment (OJL135, 30.5.91).

(12) Council Directive 91/676/EEC concerning the protection of waters against pollution caused by nitrates from agricultural sources (OJL375,31.12.91)

(13) EC, 2000, Directive 2000/60/EC of the European Parliament and of the Council of 23 October 2000 establishing a framework for Community action in the field of water policy (the Water Framework Directive). a directive on the assessment and management of flood was adopted, it is known as the Floods Directive ${ }^{(14)}$. A few earlier directives were replaced in 2008 by a directive on environmental quality standards in the field of water policy.

There are also directives connected to the European ecological network NATURA 2000(15) which have a strong relationship with the water policy:

- Council Directive 79/409/EEC of 2 April 1979 on the conservation of wild birds (the Birds Directive).

- Council Directive 92/43/EEC of 21 May 1992 on the conservation of natural habitats and of wild fauna and flora (the Habitats Directive).

Two directives concerning assessments of plans and programs $^{(16)(17)}$ and public consultation in investment related to environment ${ }^{(18)}$ have also great importance for water program, plans and investment.

From the long list of these directives, there are three directives which have the greatest importance for rural areas:

- Council Directive 91/676/EEC of 12 December 1991 concerning the protection of waters against pollution (the Nitrates Directive).

- Directive 2000/60/EC of the European Parliament and of the Council of 23 October 2000 establishing a framework for Community action in the field of water policy (the Water Framework Directive),

- Directive 2007/60/EC of the European Parliament and of the Council of 23 October 2007 on the assessment and management of floods (the Floods Directive).

Overview of legislation documents concerning water policy in the European Union shows that one can distinguish among the directives oriented on water quality standards, on control of pollutant discharged and the directives on integrated water management.

Characteristic of the directives which are the most important for the rural areas together with the problems with their implementation are presented in this paper.

\section{The Water Framework Directive}

The Water Framework Directive (WFD) was designed to coordinate the programs, plans and activities taken in order to

(14) EC, 2007, Directive 2007/60/EC of the European Parliament and the Council of 23 October 2007 on the assessment and management of flood risks (Flood Directive) (OJ L288, 06.11.2007)

(15) Council Directive 79/409/EEC of 2 April 1979 on the conservation of wild birds (the Birds Directive).

(16) Council Directive 85/337/EED of 27 June 1985 on the assessment of the effect of certain public and private projects on the environment (The EIA Directive)

(17) Directive 2001/42/EC of the European Parliament and of the Council of 27.06.2001 on the assessment of the effects of certain plans and programs on the environment (the Strategic Environmental Assessment).

(18) Directive 2003/35/EC of the European Parliament and of the Council of 26 May 2003 providing for public participation in respect of the drawing up of certain plans and programs relating to the environment. 
protect water resources ${ }^{(19)}$. The WFD assumed that: "Water is not a commercial product like any other but, rather, a heritage which must be protected, defended and treated as such." Such understanding of the role of water resources is a new approach towards the water policy, which takes into account an integrated and comprehensive way, not only domestic and economic needs, but also ecological. This approach is demonstrated by detailed objectives to be achieved as a result of WFD implementation stated as follows:

"The purpose of this Directive is to establish a framework for the protection of inland surface waters, transitional waters, coastal waters and groundwater which:

- (a) prevents further deterioration and protects and enhances the status of aquatic ecosystems and, with regard to their water needs, terrestrial ecosystems and wetlands directly depending on the aquatic ecosystems;

- (b) promotes sustainable water use based on a longterm protection of available water resources;

- (c) aims at enhanced protection and improvement of the aquatic environment, inter alia, through specific measures for the progressive reduction of discharges, emissions and losses of priority substances and the cessation or phasing-out of discharges, emissions and losses of the priority hazardous substances;

- (d) ensures the progressive reduction of pollution of groundwater and prevents its further pollution, and

- (e) contributes to mitigating the effects of floods and droughts

and thereby contributes to:

- the provision of the sufficient supply of good quality surface water and groundwater as needed for sustainable, balanced and equitable water use,

- a significant reduction in pollution of groundwater,

- the protection of territorial and marine waters, and achieving the objectives of relevant international agreements, including those which aim to prevent and eliminate pollution of the marine environment, by Community action under Article 16(3) to cease or phase out discharges, emissions and losses of priority hazardous substances, with the ultimate aim of achieving concentrations in the marine environment near background values for naturally occurring substances and close to zero for man-made synthetic substances.".

The Water Framework Directive (WFD) is a document specifying the objectives, methods and timetable for the implementation of specific objectives regarding the shaping and protection of water resources in a sustainable way, providing now and in longer-term, the required quality and quantity of water resources.

The WFD also includes the need to meet the requirements contained in other documents of the EU concerning the quality of water in protected areas including sensitiveness to eutrophication caused by domestic waste, exposed to pol-

${ }^{(19)}$ EEA, 2012e, Waterbase - Rivers, Version 8, European Environment Agency (http://www.eea.europa.eu/data-and-maps/ data/waterbase-rivers-8). lution from nitrogen compounds from agricultural sources, intended for recreational purposes, the abstraction of drinking water for the population to protect aquatic species of economic importance to the protection of habitats and species for which the maintenance of the status of water is essential to protect them. Emphasis was put on the economic aspects of water management. The introduction of the principle that water has a price aims to improve efficient use of water. WFD indicates the need to move from a sectorial planning and management of river basins in an integrated, combined with a large participation of local populations in decision-making in the field of water management. Special importance has the integration of water management in the catchment or river basin containing mountainous areas and lowlands. The first date of the implementation of the WFD is to be completed in 2015.

The WFD begins with a preamble explaining the reasons why it was needed. Content of the RWD is presented in 26 articles and 11 annexes. Article No.l contains the targets that the implementation of the Directive wants to reach. In the article No. 2 there are definitions of terms used in the Directive. Of particular note is the introduction of the definition of water status. Criteria for evaluation of water status are given in Annex V. With regard to surface water there are given definition and quality elements for the classification of ecological status for rivers, lakes, transitional waters, coastal waters, artificial and heavily modified surface water bodies. Among the most important factors necessary to determine the status of the water bodies there are listed: biological elements, composition and abundance of aquatic flora, benthic invertebrate fauna of fish fauna with age structure, hydrological regime of water bodies, quantity and dynamics of water flow, hydro morphological, chemical and physic-chemical elements supporting the biological elements, pollution by all priority substances identified as being discharged into the body of water. Status of groundwater is determined on the basis of quantitative and chemical criteria. Annex V also provides rules and range of monitoring for surface and groundwater (density of the monitoring network, frequency of the measurements, interpretation and presentation of monitoring results). Based on the collected data the status of surface water bodies is evaluated in the scale: high, good moderate, bad and poor. Groundwater bodies are evaluated in two grade scales: good or poor.

The main measures for achieving the objectives of the WFD are described in the following articles:

- Article 8: Monitoring of surface water status, groundwater status and protected areas,

- Article 9: Recovery of costs for water services,

- Article 13: River basin management plans,

- Article 14: Public information and consultation,

- Article 15: Reporting,

- Article 23: Penalties.

Among mentioned, the key tools for implementing of the WFD are river basin management plans (RBMP) and monitoring. The WFD also requires the extensive public consultation during the preparation of the RBMP. 


\section{The Water Flood Directive}

The Floods Directive is an important complement of the previously mentioned Community legislation on water management. It is equivalent to the Water Framework Directive and it is fully consistent with its provisions. The Water Framework Directive focus on issues connected with the water quality and it does not cover issues related to the floods pose a serious threat to European countries. It is estimated that in the twentieth century in Europe, floods have caused death of nearly 10 thousand people, and 10 million have been affected by the floods. Floods cause great damage to property and the environment, among others as a result of environmental contamination. Projected climate changes and pressure on the development of river valleys may increase the risk of flooding. Flood according to the Flood Directive is defined as: "a temporary covering by water of land, normally uncovered water caused by flood water in natural streams, ponds, canals and the sea". The risk of flooding is a combination of the probability of flooding and adverse impacts of floods on human health, the environment, cultural heritage and economic activity.

The primary objective of the Floods Directive is to reduce the risk of flooding and to reduce the consequences of floods. In order to reduce the risk of flooding and the consequences of the floods Member States of the European Union are obligated to develop:

- preliminary flood risk assessment (to December 2011),

- flood hazard maps and flood risk maps (to December 2013),

- flood risk management plans (to December 2015).

Preliminary flood risk assessment shall include:

- map of the river basin with the border of basin, topography and land use,

- description of the floods which have occurred in the past and which had significant negative effects on human health, the environment, cultural heritage and economic activity,

- description of the floods which have occurred in the past, if it is foreseeable that a similar phenomenon can repeat in the future,

- description of the factors which have impact on the size and consequences of flood: the topography, land use, the location of watercourses and their general hydrological and geo-morphological characteristics, including floodplains as natural retention areas, the existing flood control measures, location of residential areas, distribution of population, the position of populated areas, areas of economic activity, projected impact of climate change on the occurrence of floods.

On the basis of preliminary flood risk assessment the flood hazard maps and flood risk maps should be draw up by the end of 2013. Flood hazard maps showing the areas with risk of flooding, and flood risk maps showing the potential damage and losses of flooding. These maps indicate areas where the probability of flooding is low, medium (the occurrence of floods is less frequent than 100 years) and high.
Preliminary flood risk management plans, prepared on the basis of the flood hazard maps and flood risk maps, should indicate the list of measures to achieve the objectives of the flood risk management in river basin: flood forecasts and early warning systems, prevention, protection and proper preparation. For the areas where the risk of flooding is significant, appropriate objectives of flood risk management will be set, focusing on the reduction of potential damages and losses of flooding by using, if possible, non-technical flood control measures. The flood risk management plans will include also analysis of costs and benefits and have to consider the environmental objectives set out in the Water Framework Directive.

It is assumed that the flood risk management plans will be modified and adapted according to the needs of future conditions in the six years time periods. Member states are obliged to coordinate documents prepared within the frame of the Flood Directive with maps and reports to meet commitments of the Water Framework Directive. All documents prepared for the implementation of the Floods Directive, as well as the implementation of the Water Framework Directive should be made publicly and they should be a subject of public consultation.

\section{The Nitrates Directive}

The protection of water quality is one of the most important priorities of the European environmental policy. Nitrates Directive which was adopted in 1991 is a very important for the development of rural areas. It is a compact document consisting of a preamble, 13 articles and five annexes. Preamble indicates that the adoption of the directive is necessary because of the increasing pollution of surface water and groundwater due to, in large part, diffuse pollution from agricultural sources. It was considered that a major component of diffuse pollution is nitrogen introduced into the waters during crop production and animal husbandry. Overall, agriculture accounts for over $50 \%$ of the total amount of nitrogen introduced into the surface waters ${ }^{(20)}$.

Objective of the Directive is the reduction of water pollution caused or induced by nitrates from agricultural sources and preventing further pollution. In order to reduce the water pollution member states are obligated to designation:

- water contaminated with nitrates which contain or could contain (if no action is taken) a concentration of more than $50 \mathrm{mg} \mathrm{NO} / \mathrm{dm}^{3}$,

- natural water lakes and reservoirs, estuaries, coastal and marine waters which are eutrophic or susceptible to eutrophication,

- areas particularly vulnerable to nitrates from agricultural sources (Nitrate Vulnerable Zones - NVZs).

Member states may, instead of designating NVZs, extend the program of activities throughout the country. 10 countries (Austria, Denmark, Finland, Germany, Ireland, Lithuania, Luxembourg, Malta, the Netherlands and Slovenia) have adopted a whole territory approach. The Ni-

\footnotetext{
(20) Gordon L. J., Finlayson C.M.and Falkenmark M., 2010: Managing Water in Agriculture.
} 
trates Directive requires also developing and implementing of Action Plans to ensure the protection of water surface and groundwater against pollution caused by nitrates. Each member state should also develop the Code of Good Agricultural Practice ${ }^{(21)}$ which may be voluntarily used by farmers. Codes should contain beside others also guidance on:

- rules of fertilization of the soils in specific conditions (period, type of soil, moisture condition, weather, land geomorphology, soil permeability and water retention),

- use of fertilizers near watercourses and surface water,

- land management and organization of production on agricultural land including crop rotation,

- fertilizer card documentation.

Action Plans on the area NVZs should be obligatory implemented by farmers. These documents must include measures included in the Codes of Good Agricultural Practice and also other measures like:

- investment projects for the construction of vessels and plates for the collection and storage of natural fertilizers (derived from animal husbandry),

- education of farmers about the law and the principles of good agricultural practice,

- agricultural advisory services in developing plans for fertilizer on farms,

- control tasks by farmers,

- monitoring the quality of surface water and groundwater in areas vulnerable to nitrates.

Every four years member states are required to report on results of the water quality monitoring (content of nitrates and eutrophication of surface water), evaluation of effects of the Action Plans implementation, trends in water quality on NVZs or in the whole country.

Full implementation of the Nitrates Directive will have influence on the improvement not only of the water quality but also on the environment, agriculture, eco-tourism or agritourism in the EU. The most important effect of the Directive: reduction of nitrogen in surface water and groundwater is essential for the implementation of the Water Framework Directive, which main objectives include improvement of water quality in terms of their chemical state. It can be also concluded that the Nitrates Directive significantly support achieving of the objectives of the Water Framework Directive as well as the Groundwater Directive adopted in 2006 and others EU activities related to climate change and environmental protection.

\section{Implementation of the water directives}

The implementation of the EU directives related to water is undoubtedly a very difficult task ${ }^{(22)}$. In order to support this statement it can be said that there were 42 cases referred in

\footnotetext{
(21) IUNG PUławy, pp.70.

(22) Polish Code of Good Agricultural Practices. Ed. Irena Duer, Mariusz Fotyma. 1999.
}

the year 2000 to the European Court of Justice against the governments in matters related to the implementation of the directives on water resources even before the adoption of the Frame Water Directive ${ }^{(23)}$. The main reasons for the lack of implementation were: failure in the transposition into the national law, length of the parliamentary legislative procedures, lack of legally binding regulations for the enforcing authorities, incorrect interpretation of the concepts, internal reforms, social change, failure to implement in regions, lack of financial resources.

Progress in the implementation of the status of implementation of the most important current Water Framework Directive is presented in the reports of the European Commission. So far there were published three such reports. The first implementation report was published on 22 March 2007. This report examines the state of transposition of the WFD into the national law (Article 3 WFD) and the topics covered in Article 5: the structure of the water authorities and the environmental and economic analysis of the river basin districts.

Second implementation report was published on 1 April 2009. It presents the state of the monitoring of surface water and groundwater, which is one of the most important tools in water management (Article 8 and Annex V WFD). Third report was published on 4 November 2012. This report concerns the River Basin Management Plans (Article 13). According to the report, 23 member states have adopted and reported all their plans. 4 member states (BE, EL, ES, PT) have not adopted the plans, or adopted and reported just few plans. Overall, the Commission received 124 plans for river basin management (with 174 expected). From that amount 75\% were aimed for trans-boundary river basins.

According to the 2009 report, good ecological status of surface waters has been achieved only in $43 \%$ water bodies, and the expected state in 2015 will be achieve only in 53\% water bodies. Information about chemical status of surface waters were too unclear to establish the 2009 baseline of evaluation. In 2009, 40\% of water bodies had unknown chemical status. Good quantitative status of groundwater was estimated in $85 \%$ (2009) and in 92\% (2015). Good chemical status of grounwaters was achieved in $68 \%$ of cases (2009) and will be achieved in $77 \%$ of cases (2015).

Significant deficiencies in the monitoring occurred in the information submitted to the Commission. Approximately $15 \%$ of water bodies in the EU have unknown ecological status, and $40 \%$ have unknown chemical status. In some member states, the ecological and chemical status of groundwater is unknown for more than $50 \%$ of the water bodies.

The report favorably assessed a large effort undertaken in the member states in the development plans. However, according to the European Commission, target adopted in the WFD for 2015 will not be achieved in majority of countries. The main causes of impacts on the water environment are hydro morphological impacts, pollution and excessive discharge of water. In this report, there are also good examples of implementation of all aspects of the Water Framework Directive. Those member states which are delayed in terms of

(23) IUNG Puławy, pp. 70. 
the approval and implementation of the management plans for the river basin, have the opportunity to learn from others in order to prevent delays. Implementation of the Directive should provide water management, based on a better understanding of the risks and impacts in the basin on the basis of proper monitoring.

Reports on the implementation of the Water Framework Directive are accompanied by reports on the state of implementation of other directives regarding water. Out of the three directives described in the article, a report on the Floods Directive adopted in 2007 has not yet been developed. The state of implementation of the Nitrates Directive has been regularly presented in the reports for periods $1996-1999$, $2000-2003$ and 2004-2007. Last of them was published on 13 July 2011(25). For the first time report presented the situation in all 27 member states. According to this report, $70 \%$ of the monitoring stations showed the measured content of nitrates in surface water stable or decreasing nitrate concentrations. Only in 3\% the concentration is exceeding $50 \mathrm{mg} / \mathrm{dm}^{3}$. In $33 \%$ of the stations monitoring trophic status, the water is defined eutrophic or hypertrophic. Groundwater monitoring showed that in $66 \%$ of monitoring stations nitrate content has not changed or even decreased in comparison with the previous results reported. However, at 34 stations nitrate concentration increased in $15 \%$ of the stations exceeded the acceptable state $50 \mathrm{mg} / \mathrm{dm}^{3}$. The area of the Nitrate Vulnerable Zones covers $40,9 \%$ of the entire EU territory including the territory of member states that applied an action plans on the whole territory.

The report concludes that although there was a great progress achieved in the reduction of nitrate in waters, the full implementation of the Nitrates Directive still requires a lot of time and improvement including an increase of the Nitrate Vulnerable Zones area, expanding of the water monitoring and better implementation of the Code of Good Agricultural Practice.

\section{New water policy of the EU}

For thirty years, water policy of the EU had been making an important contribution to the protection of waters what resulted in a significant improvement of the quality of European waters. The Framework Directive adopted water management issues in integrated way. WFD set the objective of achieving good water status by 2015. The last reports showed that this ambitious goal will be achieved only in 53\% of surface water bodies. This indicates the complexity of water issues, and at the same time the need to seek for new solution. Water resources are affected by each anthropogenic activity like energy production, industry, agriculture, tourism etc. Here one should add also biotic factors (climate) and others (demography). These factors are responsible for the water pollution, lack of water (with excessive abstraction or the occurrence of drought), or excess of water (floods), as well as changes of water bodies due to hydraulic structures. Due to the ecological and chemical status of waters in the EU it is still threatening in many areas. Risk of water shortage occurs in several European regions. What is more, aquatic ecosystems are highly vulnerable to extreme events such as floods and droughts and it is necessary to make some changes in the existing EU water policy.

Therefore, the European Commission published on 14 April 2012 document titled: A Blueprint to Safeguard Europe's Water Resources (26). In the long term it will lead to balance of all the activities that have impact on waters, thus ensuring the availability of good quality water for sustainable and equitable use. This goal has already been defined in the WFD. The new plan has to help to achieve it by identifying obstacles and ways to overcome them. The basis of the plan will be greater integration of water policy objectives into other policy areas, such as the Common Agricultural Policy (CAP), the Cohesion Fund and the Structural Funds and the policy on renewable energy, transportation and integrated management of natural disasters. The plan will focus on a better solution for following issues: land use in the context of ecological and chemical status of water, vulnerability, and cross - cutting issues. In the Blueprint following actions in above mentioned problems areas have been proposed:

Land use and ecological status of water of the EU waters

- develop CIS Guidance on Natural Water Retention Measures (Green Infrastructure) and use

- Green CAP pillar I, Structural \& Cohesion Funds \& EIB loans to support Natural Water Retention Measures (through ecological focus area),

- develop CIS Guidance on ecological flow and water accounts,

- apply GMES services to detect illegal water abstraction.

\section{Chemical status and pollution of the EU waters}

- WFD enforce reporting requirements,

- Nitrate Directive: extend nitrate vulnerable zones and reinforcing action program,

- Urban Waste Water Treatment Directive: improve compliance rates on waste water treatment through long term investment planning (including the EU funds and EIB loans),

- Industrial Emissions Directive: ensure that industrial emissions permits provide for Emission Limit Values that are in line with Best Available Techniques and take to account relevant water objectives,

- Directive on the Sustainable Use of Pesticides: add to cross - compliance under the CAP,

- Pharmaceuticals: present a report on pharmaceutical and the environment,

- Environmental Quality Standards Directive: adopt the proposal of the Commission for amendments,

- enforce water price/cost-recovery obligation under the WWFD including metering when relevant,

- make water price/cost recovery an ex ante condition under Rural Development Cohesion policy funds.

\section{EU water efficiency}

- develop CIS Guidance on trading schemes and on a cost/benefit assessment,

- make water use reduction a pre-condition for some irrigation projects under the Rural Development,

- develop CIS Guidance on target-setting Guidance on 
water accounts and ecological flow,

- include water-related products in the Eco-design Working Plan,

- develop voluntary EU Ecolabel and Green Spread best practices/ tools to achieve a sustainable economic leakage level,

- public procurement criteria.

Land use and the ecological status of the EU waters: problems and solution

- enforce WFD requirements relevant to drought risk management,

- develop Flood Risk Management Plans,

- propose (regulatory) instrument on standards for water re-use,

- further develop the European Drought Observatory.

\section{Cross-cutting solutions}

- implement the Innovation Partnership on Water in Agricultural Productivity and Sustainability,

- upgrade WISE(27),

- streamline reporting \& statistic requirements,

- complete the hydro-economic model,

- continue CIS work on the science-policy interface,

- set up and use a CIS peer review system for RBMPs.

Overview of the proposed actions indicates that to the new water policy has included the new area affecting the water resources. Undoubtedly, the integration of multiple sources of impact on waters can more effectively protect the water resources than the current one. Especially, that in the Multiannual Financial Framework for 2014 - 2020 there are tools included for the integration of policies and related to proposed actions.

\section{Conclusions}

A review of the problems of water management in the rural areas showed that there are a number of contemporary conditions that restrict on the one hand improving the state of water management, but on the other hand, there are other forcing positive changes in this area. The first group of factors determining the current state of basic water facilities is related to the general state of agriculture and farm efficiency. This applies mainly to the 10 countries of Eastern Europe which in 2004 became members of the European Union. Limitation of the production associated with accession to the European Union, the competition in the market for agricultural products and poor economic condition of farms undoubtedly influenced the process of degeneration of the water facilities and the need for precise water management. Need to improve the achievement of the objectives of the European Union directives is the forcing factor. In the case of climate change, in particular global warming, programs to fight the drought, including investments in the water retention, water-saving irrigation, upgrading drainage systems, replacement of drainage ditches on the control drainage should be carried out very seriously. Significant changes in water management will be also necessary due to increased energy crops acreage.

The intensification of agricultural production in the past had a great impact on the contamination of surface water and groundwater. Water pollution may be a result of improperly stored and used fertilizers, washing of the plates manure plate, pesticides, cleaning of agricultural equipment etc. An extremely important issue within this area is also connected with a large production of domestic sewage on great number of farms. Currently, there is a great need to implement the EU directives regarding water forced in order to seek for new agricultural practices which would meet the requirements of the protection of water, soil and the environment.

\section{References}

DEMMKE, CH. 2001: Towards Effective Environmental Regulation: Innovative Approaches in Implementing and Enforcing European Environmental Law and Policy. Jean Monnet Working Paper 5/01, p. $8-10$.

FALLON, P. - BETTS, R., 2010:Climate Impacts on European Agriculture and Water Management in the Context of Adaptation and Mitigation - The Importance of an Integrated Approach. Science of the Total Environment, 408(23), 5667 - 5687.

GORDON, L. J., Finlayson C. M. and Falkenmark M., 2010: Managing Water in Agriculture.

KUDZEWICZ, Z. et. al., 2010: Zagrożenia związane z wodą. Nauka, 4/2010, $87-96$.

MAXIEJEWSKI, M. - WALCZYKIEWICZ, T. 2006: Dotychczasowe doświadczenia związane z wdrażaniem ramowej dyrektywy wodnej. Infrastruktura i ekologia terenów wiejskich, Nr 4/1/2006.

WISE, 2012: 'The Water Information System for Europe' (http: // water.europa.eu).

EEA, 2012: Report: European waters - assessment of status and pressures. No 8/2012.

EEA, 2012, European bathing water quality in 2011, EEA Report No 3/2012, European Environment Agency (http://www. eea.europa.eu/publications/european-bathing-waterquality-in-2011).

EEA, 2012, Climate change, impacts and vulnerability in Europe 2012 - An indicator-based report. EEA Report No.12/2012.

EEA, 2012: Climate change and water adaptation issues, EEA Technical report No 2/2007, European Environment Agency (http://www. eea.europa.eu/publications/technical_ report_2007_2).

EEA, 2012a: Towards efficient use of water resources in Europe, EEA Report No 1/2012.

European Environment Agency (http://www.eea.europa.eu/ publications/ towards-efficient-use-of-water).

EEA, 2012d: European waters - current status and future challenges (Synthesis). EEA Report No 9/2012. European Environment Agency, Copenhagen (http://www.eea.europa. $\mathrm{eu} / \mathrm{publications} \mathrm{C} \mathrm{c} 9=\mathrm{al} 1 \& \mathrm{c} 14=\& \mathrm{c} 12=\& \mathrm{c} 7=\mathrm{en} \& \mathrm{c} 11 \quad=5 \& \mathrm{~b}$ start $=0$ \&c5=water $)$.

EEA, 2012e, Waterbase - Rivers, Version 8, European Environment Agency (http://www.eea.europa.eu/data-and-maps/data /waterbase-rivers-8).

EC, 2000, Directive 2000/60/EC of the European Parliament and of the Council of 23 October 2000 establishing a framework for Community action in the field of water policy (the Water Framework Directive).

EC, 2007, Communication from the Commission to the European Parliament and to Council addressing the challenge of water scarcity and droughts in the European Union (COM (2007) 414 final of 18 July 2007). 
EC, 2007, Directive 2007/60/EC of the European Parliament and the Council of 23 October 2007 on the assessment and management of flood risks (Flood Directive) (OJ L288, 06.11.2007).

EC, 2010, Final Report from the Commission to the Council and the European Parliament: Second Follow-up Report to the Communication on water scarcity and droughts in the European Union (COM(2007)414 final (COM(2010)228 of 18 May 2010).

EC, 2012, A blueprint to Safequard Europe's Water Resources Consultation DocumentEuropean Commision - DirectoriateGeneral Environment (http://ec.europa.eu/environment/ consultation/pdf/blueprint.pdf).

Council Directive 79/409/EEC of 2 April 1979 on the conservation of wild birds (the Birds Directive).

Council Directive 85/337/EED of 27 June 1985 on the assessment of the effect of certain public and private projects on the environment (The EIA Directive).

Council Directive 91/271/EEC concerning urban waste - water treatment (OJL135,30.5.91).

Council Directive 91/676/EEC concerning the protection of waters against pollution caused by nitrates from agricultural sources (OJL375,31.12.91)

Directive 2001/42/EC of the European Parliament and of the Coun- cil of 27.06.2001 on the assessment of the effects of certain plans and programs on the environment (the Strategic Environmental Assessment).

Directive 2003/35/EC of the European Parliament and of the Council of 26 May 2003 providing for public participation in respect of the drawing up of certain plans and programs relating to the environment.

Polish Code of Good Agricultural Practices. Ed. Irena Duer, Mariusz Fotyma. 1999.

Report from the Commission to the Council and the European Parliament on implementation of Council Directive 91/676/EEC concerning the protection of waters against pollution caused by nitrates from agricultursl sources for the period $2000-2003$.

Commission Report (COM(2007) 120 final): "Third report on the implementation of the Nitrates Directive 91/616/EEC.

\section{Contact address/ Kontaktná adresa}

prof. dr hab. Pierzgalski Edward, Warsaw University of Life Sciences - SGGW

Faculty of civil end environmental engineering, ul. Nowoursynowska 159, 02-776 Warsaw, Poland 